\title{
打綿機のビーティング作用に関する研究
}

$\begin{array}{ccccc}\text { 福井大学工学部 } & \text { 片 } & \text { 山 } & \text { 勝 } & \text { 巳(会員) } \\ & \text { 吉 } & \text { 田 } & \text { 幸 } & \text { 吉 (会員) } \\ & \text { 加 } & \text { 藤 } & \text { 三干夫 (会員) }\end{array}$

\section{Study on the Beating Action of an Opener}

Katsumi Katayama, Kokichi Yoshida and Michio Kato

Faculty of Engineering, Fukui University, Fukui, Fukui-ken

\begin{abstract}
The studies on the beating action, which is most important in blowing processes, have been made, covering,(1)Measurement of grip pressure, it's distribution and the effect of beater gauge distance, (2) Measurement of the number of beat, (3)Measurement of beating force given to feeding cotton lap by the beater blade, and (4) Measurement of the effects of air velocity on the feeding cotton lap and the distribution of air pressure produced by the high speed revolution of beater.
\end{abstract}

The experimental results obtained are :

(1) The maximum of the grip pressure is $28.0 \mathrm{~kg}$, the grip pressure distribution region is $21.6 \mathrm{~mm}$ and the beater gauge calculated is $44 \mathrm{~mm}$ but actual beater gauge is $29.2 \mathrm{~mm}$.

(2) The number of beat is $14.8 \mathrm{~s} /$ in under the experimental conditions that the numberof revolutions of beater ; 930 r.p.m, beater gauge ; $44 \mathrm{~mm}$ the amount of feed ; $3.14 \mathrm{in} / \mathrm{sec}$.

(3) The magnitude of beating force (mean value of several recorded forces) against the cotton mass is about $1.50 \mathrm{~kg}$. The force given to single fiber with one beat is about $2 \mathrm{mg}$.

(4) The air velocity of arm parts of beater blade is about $1.50 \mathrm{~m} / \mathrm{sec}$ greater than the other parts.

The experimental formula of the relationship between distance from beater blade point and the air velocity is as follows.

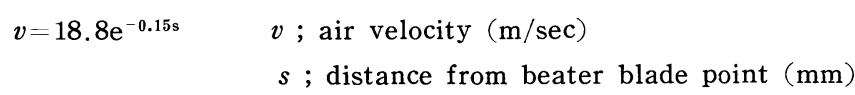

Moreover, the experimental formula of the relation between the air velocity and the air pressure is as follows.

$$
\begin{array}{r}
P=0.0984 v^{2} \quad v ; \text { air velocity }(\mathrm{m} / \mathrm{sec}) \\
P ; \text { air pressure }\left(\mathrm{g} / \mathrm{cm}^{2}\right)
\end{array}
$$

(Received December 11, 1967)

\section{摘 要}

目 的 打綿機のブレーデッド ビーターのビーティング作用について，つぎの珯点を解明する． 1.フィード ローラーの把持圧 力, 圧力分布域の測定, ビーターゲーシとの関係 2. ビート数の測定 3. ピーター ブレードによる打揧力の測定 4 . ビーターの高速 回転による風速扔よび風圧分布状態の影響

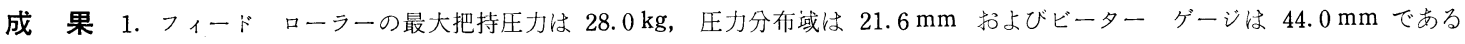
が，実質ビーター ゲージは $29.2 \mathrm{~mm}$ である.

2. ビート数は、, ビーターの回転数 930 r.p.m, ゲージ $44.0 \mathrm{~mm}$ 扔よびフィードローラーの給綿速度 $3.14 \mathrm{in} / \mathrm{sec}$ 条件下で, 14.8回/in である.

3. ピーター ブレードが綿塊へ与えた力を記録し，この力のいくつかのピークの平均值を本実験の打撃力とし，(以下この力を打撃 


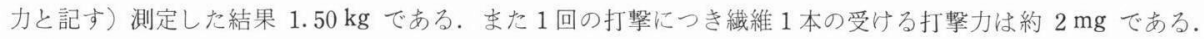

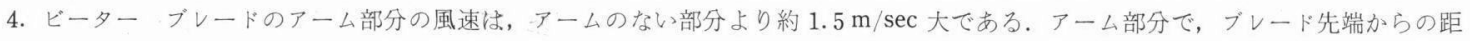
離と風速との関係実験式は $v=18.8 \mathrm{e}^{-0.15 s て ゙ あ る 。 ~} v$ は風速, $s$ は距離である。

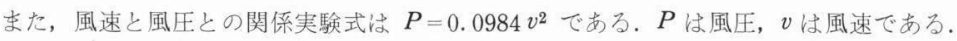

（昭和 42 年 12 月 11 日受理）

\section{1. まえがき}

最近の綿糸紡績界においては，連続自動紡績およびオ ープンエンド紡績方式が種々開発されて, 在来の混打 綿工程は短縮されているが，依然として現在でも従来の 混打綿工程を採用している工場は多数ある.

ところで, 各混打綿工程の使用目的は, 各機械の諸作 用を受けて製造されたラップむらを減少させ，さらに開 綿，混綿および除㕍老効果的にして清浄かつ均斉なラッ プを造ることにある。 そとで, 混打綿機の問題点を列举 すれば (1)開綿作用 (2)除塺作用 (3)ラップ均斉化作用 (4)繊維の損傷 (5)繊維のよじれなどである.

ことで, 纎維のよじれ現象は精紡糸のネップ発生の1 因子亡なるもので，その形状，発生の原因々なる機械取 り报い上の不手ぎわなどについては J.F. Bogdan ら1 の報文がある。また混打綿工程における䋊維の疲学およ

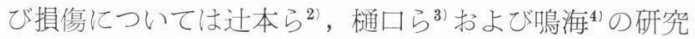
があり，ラップの長さ方向のむらに関しては鳴海ら お お よび加藤ら ${ }^{6}$, 同横方向のむらについては鳴海 ${ }^{7)}$, 大沢ら ${ }^{8)}$ および Earl Heard Jr. ${ }^{9)}$ の報文があり，また除塺につ

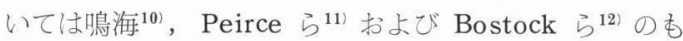
のがあり, 開綿についての報文は加藤ら ${ }^{13)}$ および鳴海 ${ }^{14}$ のものがある.

しかし混打綿工程において, 繊維の疲労, 損傷および ねじれ現象の誘因，また除塵，開綿効果およびビーター などの回転によって生ずる風速のラップむらに与える影 響之密接に関連するビーターのビーティング作用すなわ ち機械的衝撃作用, そのものについて詳細に解明してい る報文はない．

そこで，本研究は混打綿工程中の主目的で開綿および 除塵作用を左右する打綿機構の主要動作部分であるビー ティング作用に注目して実験考察する.

一般に繊維塊を解きほぐす方法として，現在広く用い られている方法は (1)ローラーによる表面速度差在利用 するもの (2)スパイクによる作用 (3)ビーターによるビ 一ティング作用であり，綿塊にビーティング作用を与え るビーターおよびシリンダーにはブレーデッド ビータ 一,キルシナ ビーター，ポーキュパイン ビーター, ガーネット ビーター,ガーネット シリンダーおよび ピンシリンダーなどが使用され，合成繊維用としては キルシナ ビーターが多く使用されている.

本研究は，そのうちブレーデッド ビーターによるビ ーティング作用について解明する.

\section{2. 実 験}

2.1 実験機台およびビーター

本実験はエキゾースト オープナー（豊和工業製）の 第 2 ビーターについて行なった. 第 1 図に使用機台の全 図，第 2 図にそのダイアグラムおよび第 1 表に本機の各 部の主要回転数 (実験条件) を示す。またビーターとフ ィード ローラーの位置関係老第 3 図に，第 4 図にビー ターの形状を示す，なお，第 4 図中「ビーターの右端加 ら」の意味はフロント側からのもので，風速および風圧

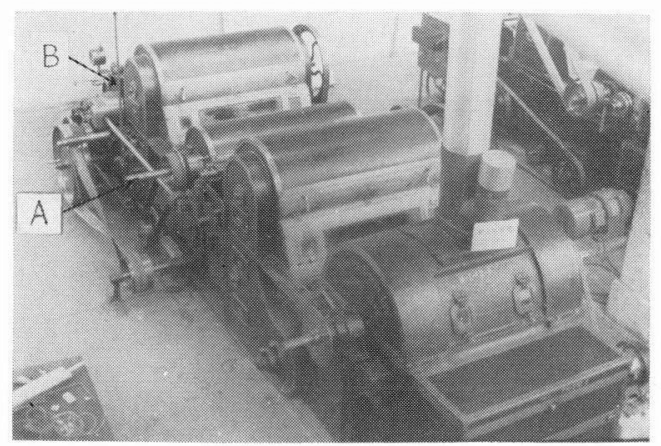

A ; ビーター軸

$\mathrm{B} ;$ ラップ マシン

第 1 図 使用機台の全図

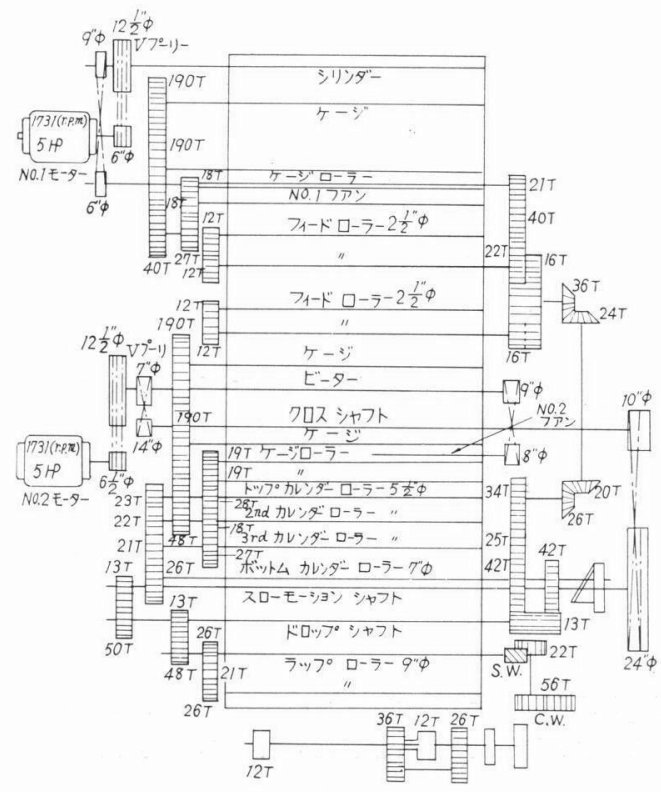

第 2 図使用機台（エキゾースト オープナー） のダイアグラム 
（第 1 表）使用機台の主要部分回転数

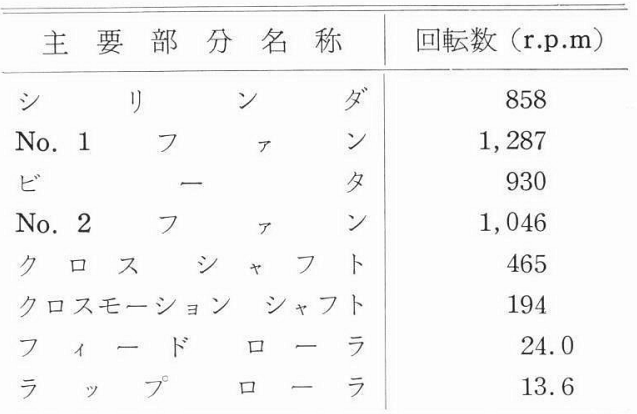

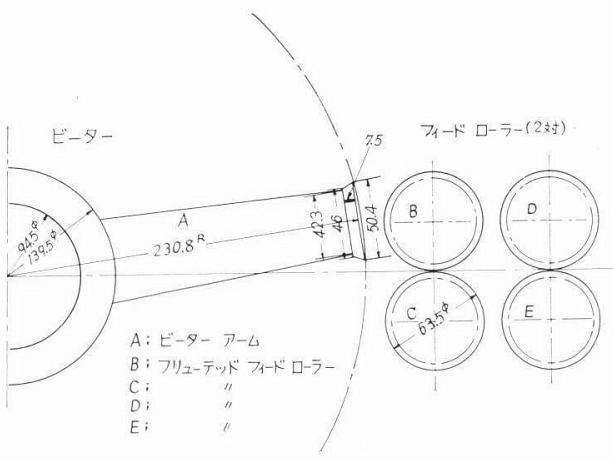

第 3 図ビーターとフィードローラー の位置関係数
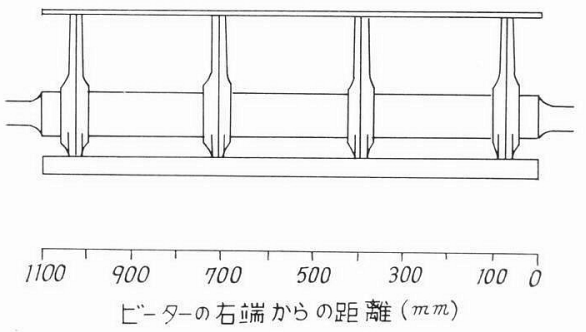

第 4 四 ビータ一形状の概略図

測定の上きに使用する。

\section{2 試 料}

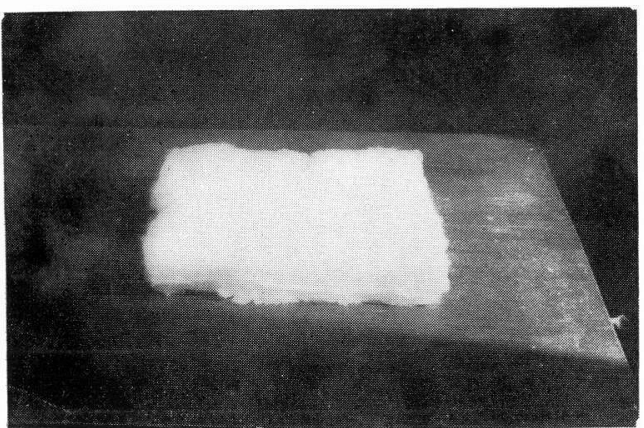

厚さ $14 \mathrm{~mm}$

幅 $200 \mathrm{~mm}$

第 5 図試料の 1 部
本実験に使用する試料を第 5 図に示す。この給綿ラッ プはフィードローラーの把持圧力, 圧力分布域および ビート数測定に使用するもので,カードウェブあがり厚 さ $14 \mathrm{~mm}$ ，幅 $200 \mathrm{~mm}$ のものを 2 枚重ねたものである。

2.3 実験方法

本実験装置の概要および実験線図第 6 図に示す。各 実験方法をつぎに示す。
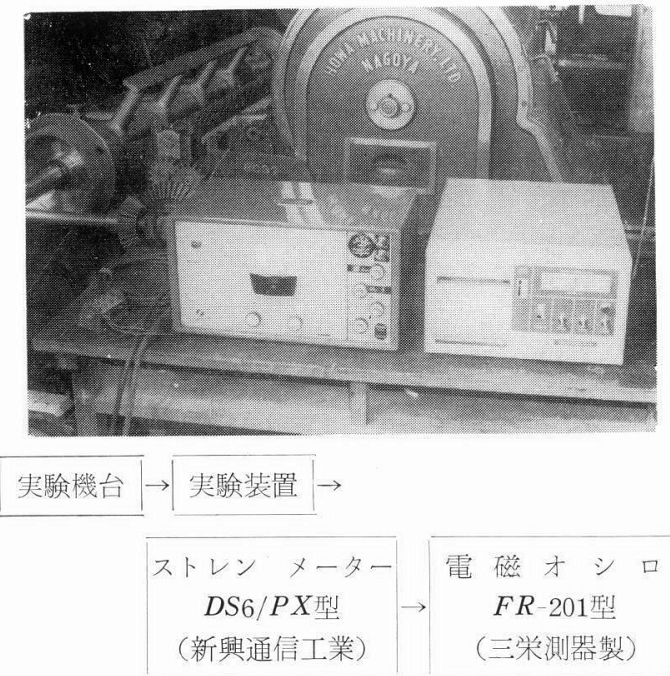

第 6 図 実験装置図わよび実験線図

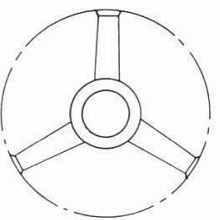

2.3. a フィードローラー把持圧力およ び圧力分布域

給綿ラップ中に燐青銅板（ストレン ゲー 淁着) をそう入し，それをフィードロー ラ一間に供給して，フィード ローラーによ る把持压力および圧力分布域を測定する.

\section{3. b ビート数}

前項乙同様にして作成した試料を実際にフ ィードローラー間在通過させ，その試料が破猿(断綿) するまで供給し，ビート数測定を行なう.

\section{3. $\mathrm{c}$ 打撃力}

ビーターブレードによる打撃力は第7図に示す装置に 測定する。第 7 図に求いて, $\mathrm{A}$ はストレンゲージ B を接 着した燐青銅板で，こ机にエバーソフトC在接着し，そ のエバーソフトの先端 $5 \mathrm{~mm}$ のころにビーターブレ ードの先端が作用するように設置し，エバーソフトの変 位をストレンメーターを通し電磁オシロに記録させる。

ここで測定に使用したエバーソフトはラップに類似し た試料すなわちラップの大きさのあるもの，醉性体であ るもの，連続測定できるものとして使用した．また燐青 銅板は測定手段上使用した。

2.3. d 風速および風圧

ビーターのまわりの風速は第 8 図に示すように，熱線 

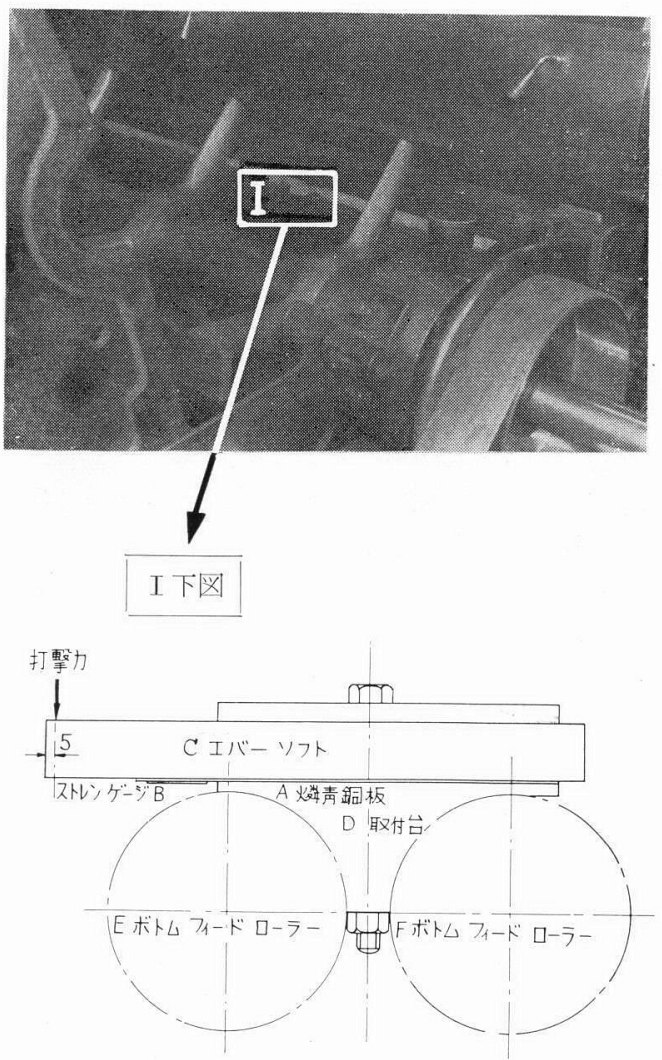

第 7 図 ビーターブレードの打撃力測定装置

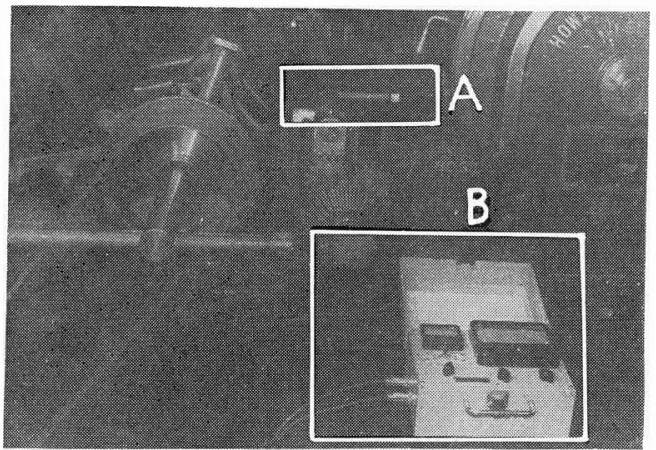

$\mathrm{A}$; 風速感知部

$\mathrm{B} ;$ 热線型微風速計本体

第 8 図 風速測定装置

型微風速計（日本計測器製）を使用して測定する。ただ しビーターの回転数は 930 r.p.m 上し,ビーターブレー ドの先端から $8.5 \mathrm{~mm}, 10.5$ $\mathrm{mm}$ および $12.5 \mathrm{~mm}$ の距離 とする。また同時にビーター アームのある部分の風速も測 定要る.

風圧は第 9 网に示す装置を 使用し，図中のAなる取付け 台をボトムフィードローラ

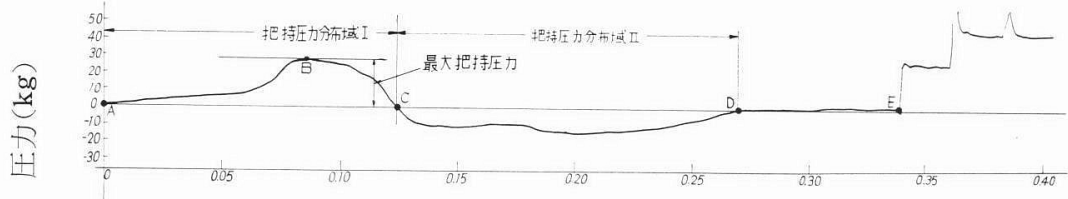

時間 $(\mathrm{sec})$

第10図 フィード ローラーの把持圧力扎よび把持圧力分布域の実験結果曲線 
一分布域 II $11.6 \mathrm{~mm}$ ，最大弓張把持圧力は一 $10.0 \mathrm{~kg}$ となり, 把持圧力分布域は $\mathrm{A} \sim \mathrm{D}$ 間で $21.6 \mathrm{~mm}$ である.

すなわち計算上のゲージは $44.0 \mathrm{~mm}$ であるが，この $21.6 \mathrm{~mm}$ という把持圧力分布域の発生により， B 点在 フィード ローラー把持点とすると $\mathrm{B} \sim \mathrm{D}$ 間は $14.8 \mathrm{~mm}$ となり実質ビーター ゲージは $44.0-14.8=29.2 \mathrm{~mm}$ となると考元られ，ゲージ決定の際には実質ビーター ゲージおよび給綿ラップの性状を考察する必要があると 考えられる.

以上よりビート数に影響する実質ビーター ゲージが 明らかになり, 硬さ, 密度および厚さがそれぞれ大なる 綿塊を供給すると実質ビーター ゲージ長が著しく小と なり, 給綿緘維長の損傷が大となり, リントの落物が増 加すると考えられる. すなわち, 打綿機より以前の工程 において, 綿塊が開綿された状態にならなければ, 打綿 機の効果は少ないと考えられる.

\section{2 ビ 一 卜数}

ビーター ブレードの作用は給綿ラップを打撃するこ とにより，開綿および除塵を行なうことである．したが って, そのビート数や綿塊に与える打撃力あるいは運動 量の大小は綿の品質之夾雑物の状態に応じて決定されね ばならない，そこで本節の実験ではそのうちのビート数 に注目する.また打撃力については次節で考察する。

一般にビート数はつぎの式で示される.

$$
\begin{aligned}
& 1^{\prime \prime} \text { 間のビート数 } B \quad B=\frac{n R}{l} . \\
& \text { ここで } \quad R ; \text { ビーターの回転数 } \\
& n ; \text {; ブレード数 } \\
& l ; 1 \min \text { の給綿長 }
\end{aligned}
$$

である.

(1)式に実験条件である $R=930$ r.p.m, $n=3$ および $l=$ $3.14 \mathrm{in} / \mathrm{sec}$ を代入して計算ビート数を求めると 14.8 回 /in となる.つぎにビート数を実測する.

第11図に実測結果の 1 例を示す。.

第11四に执いて，A点はフィード ローラー ニップ 点, $\mathrm{B}$ 点はビーターの打撃開始点, $\mathrm{C}$ 点は測定器具の破 壊を示し， B〜C間の各ピークが給綿ラップに対するビ 一ティング作用を示すむのと考えられる.

実測ビート数は第 11 図より 15.3 回/inである。乙こ で, 計算および実測ビート数を比較するとほぼ一致する

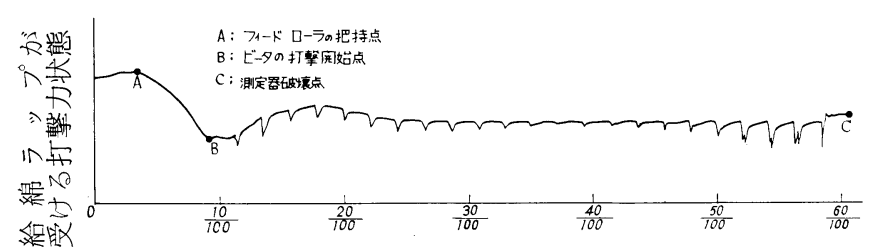

時間 (sec)
第11図 ビート数実験結果曲線
が，実測ビート数がやや大である。乙れはビーター回転 数㧍よびフィード ローラーの給綿量などのむらあるい はゲージ長の影響と考えられる。しかし，実際には写真 撮影により観察されるように，給綿絒維はフィード 口 ーラーを過ぎると下方に垂れ下がり，計算上のような多 数のビートを受けるわけではない.しかしての実測ビー 卜数の大小によってビート効果を表示する目安になる上 考えられる.

\section{3 打撃 力}

ビーターによる打撃力は開綿，除塺，繊維のよじれお よび損傷と大なる関係にあり重要である，鳴海 ${ }^{14}$ ( は開綿 効果を表示する垂下指数などを求劣さい，ブレード 型ビーターによる綿塊への作用力について詳細に考察し ている.

打綿時の打撃力は衝撃力であり, それを受けるのが不 安定な性状の綿塊層であるゆえ, 乙れを試料として打撃 力すなわ隼撃力在実験によって正確に求好ることは不 可能である. 真後 ${ }^{15}$ はこの衝撃力を一定の静荷重と仮定 して以後の計算を発展させている.

本節の実験でも, 正確な打撃力の測定は実験装置およ びその方法に難点があるため求められないが，打撃力の 大小の比較は可能であり有意性が大であると考えられる ので, 打撃力の 1 測定例を考察する.

$$
0 \quad 0.025^{\text {時 }} \begin{array}{lll}
0.05^{\text {月月 }} & (\mathrm{sec}) \\
0.075 & 0.10
\end{array}
$$

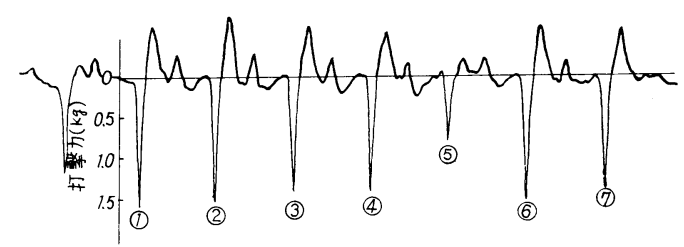

第12図 ビーターの打撃力実験結果曲線

第 12 図にビータ一の打撃力測定結果の 1 例を示す．第 12図に㧍いて，最大打撃力(1)，(2)，(3)，(4)および(6)の平 均值をむって打撃力とすると, 1 回の打撃力值は約 1.50 $\mathrm{kg}$ である.ここで, 1 回の打撃につき瀻維 1 本の受け る打撃力む求妨机る. その方法として, 第 7 図に示し たエバーソフトの断面積は幅 $30 \mathrm{~mm}$, 厚さ $10 \mathrm{~mm}$ であ るゆえ $30 \times 10 \mathrm{~mm}^{2}$ である。 そこで $30 \times 10 \mathrm{~mm}^{2}$ 内にあ る断面繊維本数は, 簡単のために綿瀻維を円形 とし，たて，よこ方向ともに整然と配列し，同 密度之仮定する之綿繊維の太さが16〜20 $\mu^{16)}$ で あるから，たて方向に 500 本およびよて方向に 1500 本並び， $7.5 \times 10^{5}$ 本になる．したがって， 1 回の打撃力は $1.50 \mathrm{~kg}$ より, 1 回の打撃によ り綿繊維 1 本の受ける打撃力は約 $2 \mathrm{mg}$ とな る. 
また一方，打撃力の時間に対する関係を考察するとピ

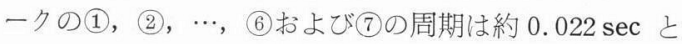
なり，後記の 3.4.bで考察するビーターによる打撃力の 周期に一致することは明白であり，前記のピークをビー ターによる打撃と考えたことを裏付けている．つぎに(1) 〜(2)，(2)〜(3)および(3)〜(4)間などを考察すると，第 1 番 目の最大のピークがビーターの打撃力そのあのであり, 第 2 および第 3 番目のピークはビーター ブレードの打 撃に対する燐青銅板およびエバーソフトの抵抗力を表わ している上考えられる. この打撃によって打ち取られた 給綿ラップを写真撮影で観察すると, 第13図に示すよう に刘物で切り取られたかのようになっている. またビー ターによる打撃後のラップ端は, 第 2 ケージ ファンの 影響によって, 水平方向の力を受ける傾向にあり, 繊維 長の損傷率増加を示すと考えられる.

ここで打撃力測定について考察すると, 従来の打撃力 という観念を捨て, 打撃力に代わって, 打撃による運動 量（またはエネルギー）を測定し，綿層を供給した場合
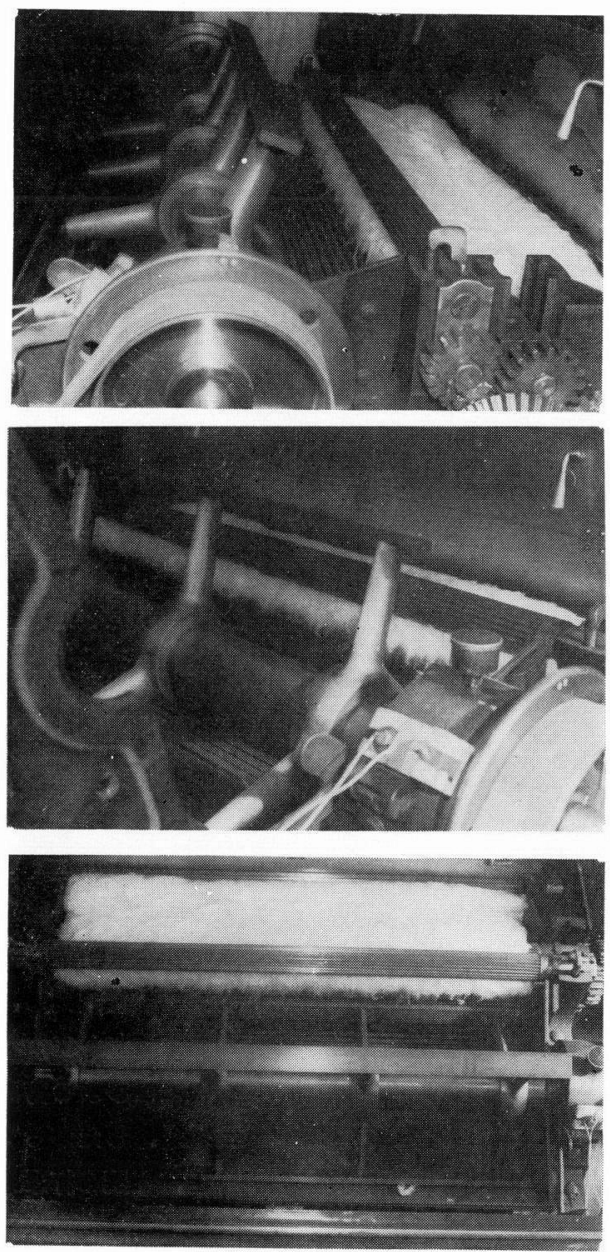

第13図 ビーティング作用後の給綿ラップ状態図
としない場合との運動量の差を測定し, 実際にビーター ブレードの綿層への打撃の効果ならびに影響を考察する 方が，よりよい精度が得られると考えられる．

\section{4 風速および風圧}

混打綿工程においての空気流についての報文17のうち で, 鳴海 ${ }^{7)}$ はビーター〜ケージ間の綿塊輸送管路内に不 規則な空気流が発生し，綿塊の均等な輸送を妨げ，ラッ プの长周期的横むらの誘発原因になると報告している.

そこで, 本節の実験では, フィードロローー〜ビー ターブレード間の風速および風压を測定する.すなわ ち, ビーターの高速回転によってビーター周辺部に発生 する空気流分布状態の給綿ラップに対する影響を求め る.

3.4. a 風速

第 14 网にビーター回転数 930 r.p.m のときの風速測定結

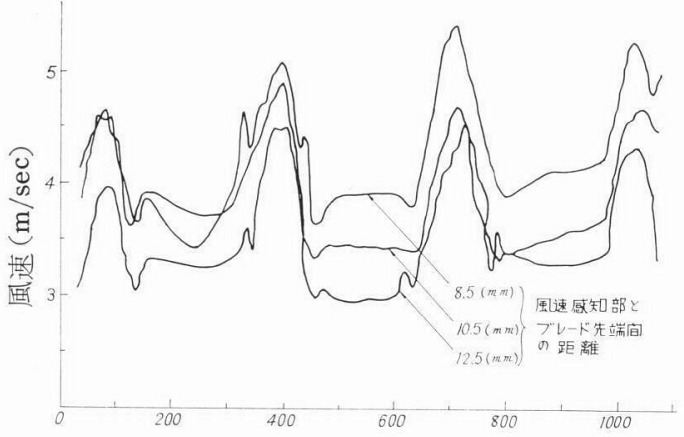

距離 $(\mathrm{mm})$

第14図 風速とビーター右端からの距離上の関係図

果の 1 例を示す．第 14 図中の $8.5 ， 10.5$ および $12.5 \mathrm{~mm}$ は測定器感知部とビーターブレード先端間の距離であ る・第14図より明らかなように，4つのピークが現われ ている、こ机はブレーデッド ビーター アームの位置 を示するのであり，との部分の風速は他の部分の風速よ り約 $1.5 \mathrm{~m} / \mathrm{sec}$ 大なるととが認められる。この事実よ り，ビーター周辺部の空気流は給綿ラップに横方向にむ らのある力を与えることを示し，乙れによってラップの 横むらが誘発されているのではないかと考えられる.

また一方，ビーター ブレード先端からの距離上風速 との関係在求める. その結果第 15 四に示し, 両者の近 似関係式を(2)式に示す。

$$
v=18.8 e^{-0.15 \mathrm{~s}} \text {. }
$$
ここで, $v$; 風速 $(\mathrm{m} / \mathrm{sec})$

$$
s \text {; ビーター ブレード先端加らの距離 }(\mathrm{mm})
$$

である、第15网中, 点線部分は推定曲線である。ブレー ド先端からの距離之風速の関係は指数曲線的であり, こ れはビーターの高速回転によって生ずる空気流の境界層 が原因とも考察でき，綿塊層に対しての影響も無視でき ない上考えられる。 


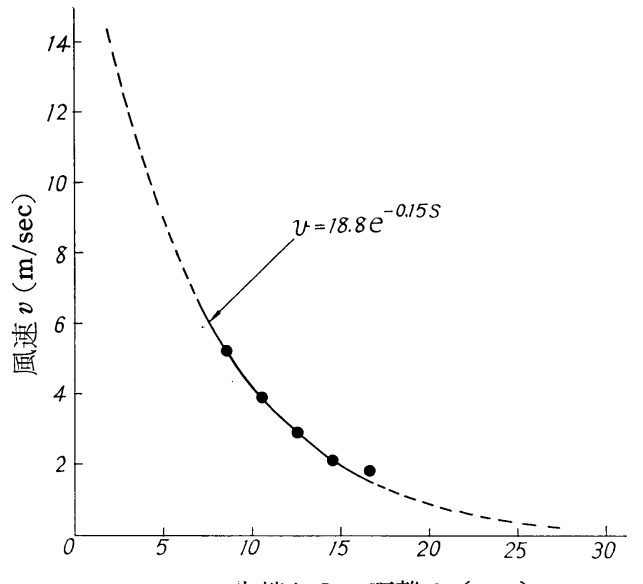

ビーター先端からの距離 $S(\mathrm{~mm})$

第15図 風速とビーター先端からの距離との関係図

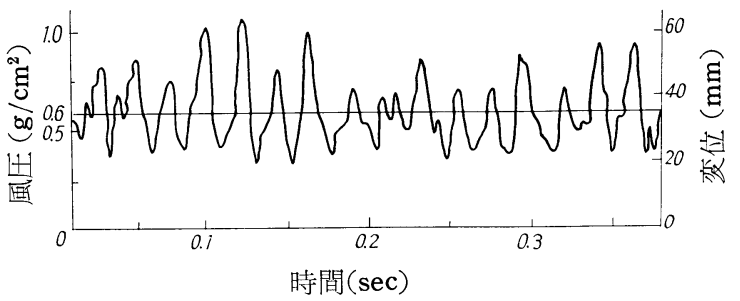

第16図 風圧実験結果曲線

$3.4 . \mathrm{b}$ 風圧

第16図に風圧測定結果の 1 例を示す。第16図より明ら かなように，風圧は時間に対して一見ランダムな曲線で ある. そこでこの風圧変動曲線を考察するのに，その変 動状態に注目してむら解析を試みる。風圧変動のむら は，ひいてはラップのたて方向のむらの遠因になるとも 考えられ重要である. そこで, むら解析法として風圧変 動曲線の自己相関関数を求め, その結果を第 17 図に示 す. 第17罒より明らかなように，乙の風圧抢らの周期は 11/500 sec である. また一方, ビーター ブレードによ る綿塊に与える打撃の周期は, 実験条件のビータ一回転

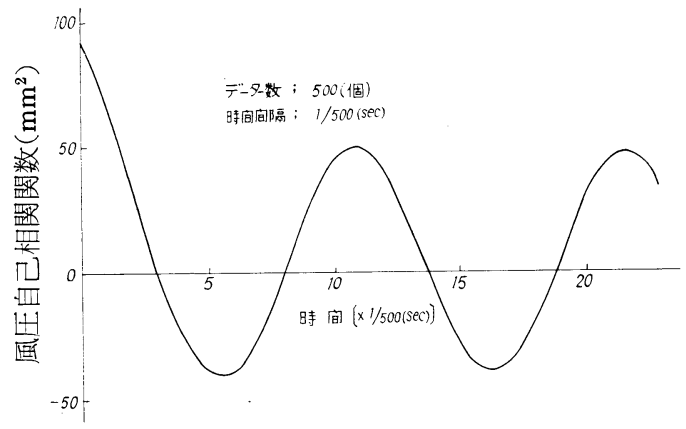

第17図 風圧の自己相関関数
数は 930 r.p.m で 3 ビーター ブレードであるから， $60 /(930 \times 3) \div 0.022 \mathrm{sec}$ となり風圧むらの周期と一致す る.すなわち，風圧むら周期の主原因はビータ一回転そ のあのによることは明らかである.しかし，乙の周期を ラップ長に換算すると，フィード ローラーの給綿速度 が $3.14 \mathrm{in} / \mathrm{sec}$ であるから，そのラップ長に対する周期 的な長さは 0.07 in というごくわずかなすのであり，乙 の風圧によるラップ長方向の効果は無視できるほど小で あると考えられる。

3.4. c 風速・風圧間の実験式およびまとめ

風速之風圧との関係式を求めるために, まず平均風速 を(2)式のビーター ブレード先端からの距離と風速との 関係式 $v=18.8 e^{-0.15 \mathrm{~s}}$ より次式で求める.

$$
\frac{1}{38.2} \int_{1.8}^{40} 18.8 e^{-0.15 \mathrm{~s}} d s \div 2.5(\mathrm{~m} / \mathrm{sec})
$$

また一方，風圧測定結果より平均風圧は $0.6 \mathrm{~g} / \mathrm{cm}^{2}$ と なる.ところで風圧は風速の 2 乗に比例するので，(4)式 に示す実験式が得られる.

$$
P=0.098 v^{2}
$$

$$
\begin{array}{r}
\text { こで, } P \text {; 風圧 }\left(\mathrm{g} / \mathrm{cm}^{2}\right) \\
v \text {; 風速 }(\mathrm{m} / \mathrm{sec})
\end{array}
$$

である。

以上の実験結果および考察より，給綿ラップに対する ビーター ブレード周辺部の影響は少なく，ケージフ アンの吸気作用による効果の方が大であると考えられ る.しかし，ビータ一周辺の空気流の乱れがケージ フ ァンによる空気流に影響すると考察され, これらの相互 作用によって生ずる乱流効果は軽視するととはできない と考えられる.

\section{4. むすび}

本研究の結果, 明らかにされた事項はつぎの通りであ る。

(1) フィード ローラーの最大把持圧力は $28.0 \mathrm{~kg}$, その圧力分布域は $21.6 \mathrm{~mm}$ およびビーター ゲージは 計算上では $44.0 \mathrm{~mm}$ であるが，実質ビーター ゲージ は $29.2 \mathrm{~mm}$ である。

(2) ビート数は 14.8 回/inである.なお実験条件はビ ーター回転数 930 r.p.m, ゲージ長 $44.0 \mathrm{~mm}$ およびフ ヘード ローラー給綿速度 $3.14 \mathrm{in} / \mathrm{sec}$ である。

(3) ビーター ブレードの給綿ラップに与える打撃力 は $1.50 \mathrm{~kg}$ である. また 1 回の打撃につき繊維 1 本の受 ける打撃力は $2 \mathrm{mg}$ である.

（4）ビータ一周辺部の平均風速は $2.5 \mathrm{~m} / \mathrm{sec}$, 平均風 王は $0.6 \mathrm{~g} / \mathrm{cm}^{2}$ である.ビーター ブレード先端からの 距離と風速との関係式は $v=18.8 e^{-0.15 \mathrm{~S}}$ である. ここ で， $v$ は風速， $s$ は距離である．また風速之風圧間の関 
係実験式は $P=0.098 v^{2}$ である．乙こで， $P$ は風圧， $v$ は風速である。

以上のように，本研究は混打綿工程の主目的である開 綿および除塵効果増大にもっとも関連の深いビーティン グ作用について実験を試みたが，他のビーターおよびシ リンダーとの性能比較, 各機械内の空気流の給綿ラップ に対する影響, 繊維損傷, 真のビート数および打撃力の 測定を今後の課題としたい.

しかし, 本研究の解析結果を 1 測定例として, ビーテ ィング作用および各種混打綿機械の性能および比較解析 を求めれば, 在来の経過的研究に一歩前進の端緒を与え ることができると考えられる。

最後に，本研究に終始協力された竹下健および山崎勝 義の両君に感謝する次第である.

\section{参考文献}

1) J. F. Bogdan, Ivan Y.T. Feng ; Text. World (1952-5)

2) 辻本, 元治 ; 本誌, 5, 5, 4, 251 (1952) 同上；本誌， 5, 5, 7, 254 (1952)
3) 樋口, 町田; 本誌, 14, 3, 6, 172 (1961)

4) 鳴海; 本誌, $11,8,29,548$ (1958)

5) 鳴海, 森下 ; 本誌, 2, 3, 1 (1949) 同上 ; 本誌, 3, 11, 24 (1950) 鳴海, 勝西, 三好 ; 本誌, 4, 11, 23 (1951)

6 ) 加藤, 吉田, 片山 ; 本誌, 19, 3, 29, T 91 (1966)

7 ) 鳴海 ; 本誌, 12, 2, 41, 131 (1959)

8 ）大沢, 山賀 ; 本誌, 15，6，51，440（1962）

9 ) Earl Heard Jr. ; Text. Res. J. 24, 6, p.555 (1954)

10）鳴海；本誌，11，3，27，179 (1958) 同上; 本誌, 11, 4, 13, 239 (1958) 同上; 本誌, 11, 6, 14, 386 (1958)

11) F. T. Peirce, J.K. Kelly and Mary H. Coleman; J. Text. Inst, 46, 2, T 28 (1955)

12) Bostock, Freeman, Shorter and Williams; J. Text. Inst, 46, 3, T 171 (1955)

13）加藤, 坂奥, 吉田 ; 本誌, 8， 1，50，50（1955） 同上 ；本誌，9， 3, 20, 159 (1956) 同上 ; 本誌, 10, 3, 46, 300 (1957) 加藤, 吉田 ; 本誌, 11, 9, 30, 625 (1958)

14）鳴海; 本誌, 10, 10, 13, 768 (1957)

15）真後; 本誌, 3, 2, 14, 63 (1950)

16）日本紡績協会調査部工務課；瀻維技術デー夕集 p. 27 （1964）大阪，日本紡績協会

17）樋口；本誌， 11，7，9，452（1958）など 